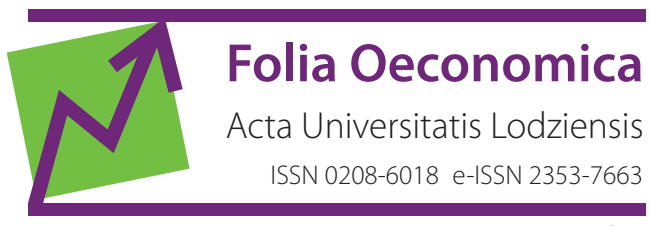

www.czasopisma.uni.lodz.pl/foe/

$3(348) 2020$

DOI: http://dx.doi.org/10.18778/0208-6018.348.08

\title{
Henryk Gurgul
}

AGH Akademia Górniczo-Hutnicza w Krakowie, Wydział Zarządzania

Samodzielna Pracownia Zastosowań Matematyki w Ekonomii, gurgul@zarz.agh.edu.pl

\author{
Marcin Suder \\ AGH Akademia Górniczo-Hutnicza w Krakowie, Wydział Zarządzania \\ Samodzielna Pracownia Zastosowań Matematyki w Ekonomii, msuder@agh.edu.pl
}

\section{Struktura wypłat z bankomatów z uwzględnieniem typów ich lokalizacji ${ }^{1}$}

Streszczenie: Jednym z elementów procesu zarządzania siecią bankomatową jest dogłębna analiza struktury wypłat z poszczególnych bankomatów oraz z określonych grup bankomatów o zbliżonej lokalizacji. Jest to element niezbędny przy podejmowaniu decyzji o wyborze lokalizacji dla nowych bankomatów oraz o likwidacji określonego bankomatu lub bankomatów z jakiegoś typu lokalizacji. Ważnymi elementami struktury wypłat, zwłaszcza w ujęciu opłacalności funkcjonowania bankomatu, są liczba oraz wielkość wypłat z bankomatu. Liczba wypłat z bankomatu jest związana bezpośrednio z przychodami operatora z tytułu opłaty interchange oraz reklam wyświetlanych podczas korzystania z bankomatu przez klienta. Im większa liczba operacji wypłat, tym większe przychody dla operatora sieci. Z kolei wielkość wypłat powiązana jest bezpośrednio z kosztami, jakie ponosi operator. Większe wypłaty z danego bankomatu oznaczają wyższe koszty związane z przygotowaniem i dostarczeniem gotówki do bankomatu oraz jej „zamrożeniem” w bankomacie.

Celem przeprowadzonych badań jest wskazanie tych typów lokalizacji bankomatów, które potencjalnie przynoszą największe zyski, tzn. występuje w nich najwięcej wypłat o stosunkowo niskiej wartości. Dodatkowo zweryfikowano, czy występuje istotne zróżnicowanie w liczbie wypłat oraz w wielkości wypłat pomiędzy grupami bankomatów z różnych typów lokalizacji.

W analizie wykorzystano szeregi czasowe liczby i wielkości wypłat z bankomatów jednego z największych operatorów sieci bankomatowych w Polsce. Dane dotyczą bankomatów zlokalizowanych w województwach małopolskim i podkarpackim. W celu porównania struktury wypłat oraz wykazania ich zróżnicowania w poszczególnych bankomatach i grupach bankomatów wykorzystano podstawowe miary statystyczne oraz wybrane testy statystyczne. W wyniku przeprowadzonych badań zostały

1 Publikacja finansowana z subwencji dla WZ AGH na utrzymanie i rozwój potencjału badawczego. 
wyodrębnione te typy lokalizacji, w których instalowanie bankomatów z dużym prawdopodobieństwem przyniesie większy dochód. Przeprowadzone analizy mogą posłużyć operatorom bankomatowym przy wyborze typu lokalizacji.

Słowa kluczowe: lokalizacja bankomatów, struktura wypłat, zarządzanie napełnianiem bankomatów gotówką

JEL: G21, G32, G39

\section{Wprowadzenie}

Początek drugiej dekady XXI wieku przyniósł nieoczekiwanie niekorzystną zmianę dla operatorów sieci, zwłaszcza tych niezależnych. Wydawcy kart płatniczych, tworzący organizacje płatnicze Visa i MasterCard, podjęli decyzję o obniżeniu opłaty interchange do poziomu 1,2-1,3 zł. Taka obniżka sprawiła, że przychody operatorów bankomatowych z tytułu tych opłat spadły o ponad $60 \%$. Konsekwencją tych decyzji było chwilowe zahamowanie rozwoju sieci oraz spadek liczby bankomatów.

Jednocześnie początek drugiej dekady XXI wieku charakteryzował się zwiększeniem zainteresowania ze strony sprzedawców oraz usługodawców bezgotówkowymi formami płatności. Instalowano coraz więcej terminali do płatności bezgotówkowej. Ta forma płatności była istotnym zagrożeniem dla rentowności biznesu bankomatowego. W latach 2011-2014 dynamika rozwoju płatności bezgotówkowych nie była duża z powodu wysokich opłat interchange, jakie pobierały organizacje płatnicze od właścicieli sklepów i firm usługowych. Sytuacja znacząco zmieniła się w kolejnych latach, kiedy istotnie obniżono te opłaty, co znacznie zmniejszyło koszty użytkowania terminali. Jak wskazują Polasik i Maciejewski (2017), obniżki te przyczyniły się do wyraźnego zwiększenia się liczby terminali POS w punktach handlowo-usługowych. W konsekwencji zwiększyła się liczba płatności bezgotówkowych, a terminale POS stały się poważną konkurencją dla bankomatów.

Obniżenie zysków z tytułu opłat interchange oraz coraz większa popularność terminali bezgotówkowych sprawiły, iż operatorzy bankomatowi zaczęli likwidować mniej rentowne bankomaty oraz poszukiwać takich lokalizacji dla bankomatów, aby zyski z ich funkcjonowania były na oczekiwanym poziomie.

W przypadku sieci bankomatów jedną z kluczowych kwestii jest zarządzanie decydujące o lokalizacji, wielkości i czasie wypłat, a także logistyce konwojów dowożących gotówkę. To właśnie te czynniki wpływają w decydującym stopniu na koszt funkcjonowania bankomatów. Jak już wspomniano, wynagrodzenie operatora sieci jest bezpośrednio związane z liczbą wypłat z bankomatu. Natomiast wielkość wypłat nie ma wpływu na wynagrodzenie, a przekłada się na koszty, jakie ponosi operator sieci. Te koszty związane są z „mrożeniem” gotówki oraz jej transportem do bankomatu. 
Odpowiednie zarządzanie siecią bankomatów wymaga od operatora dogłębnej analizy własności szeregów czasowych wypłat z bankomatów. Poznanie struktury liczby wypłat z poszczególnych bankomatów daje możliwość oceny rentowności danej maszyny. Ważnym czynnikiem w kontekście opłacalności działania konkretnego bankomatu jest też wielkość wypłat z niego. Im jest ona mniejsza, tym mniejsze są koszty związane z przygotowaniem gotówki i jej kosztami. Operator będzie zatem poszukiwał takiej lokalizacji dla bankomatu, w której jest dużo wypłat o niskiej wartości.

W polskiej literaturze ekonomicznej obok cyklu prac Gurgula i Sudera (2012; 2013a; 2013b; 2013c; 2015; 2018) zagadnienia dotyczące problematyki bankomatów w Polsce zostały poruszone między innymi w pracach Górki (2011; 2013), Górki i Chodnickiej (2012) oraz Kufla (2010).

W przywołanych pracach można także znaleźć szczegółowy przegląd zagranicznej literatury przedmiotu, dotyczącej zagadnień technicznych, organizacyjnych, a przede wszystkim ekonomicznych funkcjonowania bankomatów.

Do ważniejszych prac zagranicznych autorów, dotyczących bankomatów, należą publikacje Estevesa (2009), Holdena i El-Bannany'ego (2004), Kondo (2010), Mestera (2009), Clevelanda i Devlina (1980), Amromina i Chakravortiego (2007), Boeschotena (1998), Snellmana i Virena (2009), Brentnalla, Crowdera i Handa (2008; 2010), Carlsena i Storgaarda (2010). Ich omówienia można znaleźć w artykule Gurgula i Sudera (2013b).

Celem niniejszego opracowania jest zbadanie, czy typ lokalizacji wpływa na strukturę wypłat $\mathrm{z}$ bankomatów wyrażoną liczbą i wielkością wypłat. Ponadto zweryfikowano, czy bankomaty pochodzące $\mathrm{z}$ tego samego typu lokalizacji mają podobne własności wypłat.

Należy zwrócić uwagę na fakt, iż przedstawiony problem badawczy nie był poruszany w polskim piśmiennictwie naukowym i trudno odnieść się do publikacji dotyczących opłacalności funkcjonowania bankomatów w poszczególnych typach lokalizacji. Wynika to z tego, że naukowcy nie mają dostępu do tego typu oryginalnych danych i nie są publikowane wyniki tego rodzaju badań. Niniejszy artykuł może stanowić pewnego rodzaju uzupełnienie tej luki.

Struktura artykułu jest następująca: $\mathrm{w}$ drugim punkcie podane są informacje dotyczące lokalizacji bankomatów, z których wypłaty zostały poddane analizie, w trzecim i czwartym przedstawiono wyniki empiryczne badań, a ostatnia część artykułu obejmuje wnioski z badań.

\section{Opis danych}

W przeprowadzonej analizie wykorzystano dane dotyczące wypłat z bankomatów jednej z największych sieci bankomatowych w Polsce. Ze względu na tajemnicę handlową autorzy nie podają bliższych szczegółów dotyczących źródeł tych 
danych, bo takie było zastrzeżenie firmy udostępniającej je. Dane dotyczą wypłat $z$ bankomatów zainstalowanych na terenie województw małopolskiego oraz podkarpackiego. Są to dane opisujące dzienne wielkości i liczby wypłat z poszczególnych bankomatów w okresie od stycznia 2011 roku do grudnia 2012 roku. Do analizy wybrano szeregi czasowe wypłat z tych bankomatów, które zainstalowane są w najbardziej popularnych lokalizacjach. Aby analiza wpływu lokalizacyjnego była wiarygodna, wybrano te typy lokalizacji, w których jest minimum 20 bankomatów. Były to lokalizacje typu: oddział bankowy, hipermarket, sklep, stacja paliw oraz centrum handlowe. W tych lokalizacjach znajdowało się łącznie 217 bankomatów.

Ponieważ wybrane dane pochodzą $\mathrm{z}$ bankomatów nie tylko o różnym typie lokalizacji, ale również z różnych miejscowości, dlatego jako drugi czynnik lokalizacyjny wprowadzono kategorię miejscowości. Miastom, w których zainstalowano analizowane bankomaty, przyporządkowano kategorię według kryterium dostępności do bankomatu (wyrażonej w liczbie osób przypadających na jeden bankomat). Zasada przyznawania kategorii dla miejscowości była następująca:

1) kategoria A - do 1000 osób na bankomat,

2) kategoria B - od 1000 do 1200 osób na bankomat,

3) kategoria C - od 1200 do 1500 osób na bankomat,

4) kategoria $\mathrm{D}$ - powyżej 1500 osób na bankomat.

W Tabeli 1 przedstawiono informacje o liczebności bankomatów w poszczególnych klasach lokalizacyjnych.

Tabela 1. Liczba i odsetek bankomatów w poszczególnych lokalizacjach i kategoriach dostępności

\begin{tabular}{|c|c|c|c|c|c|c|c|c|c|c|}
\hline \multirow[t]{2}{*}{ Typ lokalizacji } & \multicolumn{2}{|c|}{$\begin{array}{c}\text { Kategoria } \\
\text { A }\end{array}$} & \multicolumn{2}{|c|}{$\begin{array}{c}\text { Kategoria } \\
\text { B }\end{array}$} & \multicolumn{2}{|c|}{ Kategoria C } & \multicolumn{2}{|c|}{$\begin{array}{c}\text { Kategoria } \\
\text { D }\end{array}$} & \multicolumn{2}{|c|}{ Razem } \\
\hline & $\mathbf{N}$ & $\%$ & $\mathbf{N}$ & $\%$ & $\mathbf{N}$ & $\%$ & $\mathbf{N}$ & $\%$ & $\mathbf{N}$ & $\%$ \\
\hline Centrum handlowe & 2 & 0,92 & 34 & 15,67 & 6 & 2,76 & 2 & 0,92 & 44 & 20,28 \\
\hline Hipermarket & 2 & 0,92 & 24 & 11,06 & 2 & 0,92 & 5 & 2,30 & 33 & 15,21 \\
\hline Oddział bankowy & 3 & 1,38 & 47 & 21,66 & 15 & 6,91 & 10 & 4,61 & 75 & 34,56 \\
\hline Sklep & 4 & 1,84 & 28 & 12,90 & 5 & 2,30 & 2 & 0,92 & 39 & 17,97 \\
\hline Stacja paliw & 5 & 2,30 & 19 & 8,76 & 0 & 0,00 & 2 & 0,92 & 26 & 11,98 \\
\hline Razem & 16 & 7,37 & 152 & 70,05 & 28 & 12,90 & 21 & 9,68 & 217 & 100,00 \\
\hline
\end{tabular}

Źródło: opracowanie własne na podstawie danych uzyskanych od operatora sieci

Wśród analizowanych bankomatów zdecydowanie najwięcej zlokalizowanych jest w oddziałach bankowych (ponad jedna trzecia), natomiast najmniej na stacjach benzynowych (około 12\%). Ze względu na dostępność bankomatów największą grupę stanowią miejscowości o kategorii B. Wynika to z faktu, iż do tej grupy należy Kraków, w którym zainstalowanych jest najwięcej bankomatów. Najmniej liczne są bankomaty zlokalizowane w miejscowościach o największej dostępności bankomatu. 
W niniejszych rozważaniach analizie statystycznej poddane zostaną szeregi czasowe liczby dziennych wypłat z bankomatów, wielkości wypłat oraz średniej dziennej pojedynczej wypłaty. W kręgu zainteresowania będą głównie średnie wartości dla opisanych danych oraz ich współczynnik zmienności. W celu zweryfikowania, czy typ lokalizacji bankomatu wpływa istotnie na liczbę oraz wielkość wypłat, zostanie zastosowany test Kruskala-Wallisa (por. Kruskal, Wallis, 1952) z przyjętym poziomem istotności 0,05 .

Dodatkowo dla każdego z bankomatów zostanie przeprowadzona analiza struktury wielkości wypłat, polegająca na określeniu, jaki procent wypłat należy do jednej z wyszczególnionych grup według następującego podziału: grupa 1 - wypłaty do $100 \mathrm{zł}$, grupa 2 - wypłaty powyżej $100 \mathrm{zl}$, ale nie większe niż $1000 \mathrm{zl}$, grupa 3 - wypłaty powyżej 1000 zł.

\section{Wyniki analizy dla wybranych bankomatów}

W związku z dużą liczbą badanych bankomatów nie jest możliwa dokładna analiza danych generowanych przez nie oraz podanie szczegółowych wyników dla każdego z bankomatów. Jednak w celu zobrazowania struktury, liczby i wielkości średniej wypłaty szczegółowej analizie poddano najpierw wypłaty z pięciu wybranych bankomatów pochodzących z różnych typów lokalizacji.

W Tabeli 2 zamieszczono informacje o lokalizacji wybranych bankomatów, które zostały tak dobrane, aby reprezentowały każdy typ lokalizacji oraz każdą kategorię dostępności.

Tabela 2. Informacje o lokalizacji wybranych bankomatów

\begin{tabular}{|l|c|c|c|c|c|}
\hline Kategoria lokalizacja & Bankomat 1 & Bankomat 2 & Bankomat 3 & Bankomat 4 & Bankomat 5 \\
\hline Województwo & małopolskie & podkarpackie & małopolskie & małopolskie & podkarpackie \\
\hline Miejscowość & Kraków & Rzeszów & Zakopane & Chełmek & Mielec \\
\hline Typ lokalizacji & $\begin{array}{c}\text { centrum } \\
\text { handlowe }\end{array}$ & $\begin{array}{c}\text { oddział } \\
\text { bankowy }\end{array}$ & stacja paliw & sklep & hipermarket \\
\hline Kategoria dostępności & B & B & A & D & C \\
\hline
\end{tabular}

Źródło: opracowanie własne na podstawie danych uzyskanych od operatora sieci

Pierwsza część analizy związana była z badaniami własności statystycznych szeregów czasowych liczby oraz średnich dziennych wypłat z wybranych bankomatów. Na początku analizie poddano szeregi czasowe liczby wypłat z tych bankomatów. Na Rysunku 1 znajdują się wykresy szeregów czasowych liczby wypłat tygodniowych ${ }^{2} \mathrm{w}$ wybranym okresie.

2 Aby wykresy były bardziej czytelne, użyto szeregów czasowych tygodniowych, a nie dziennych. 


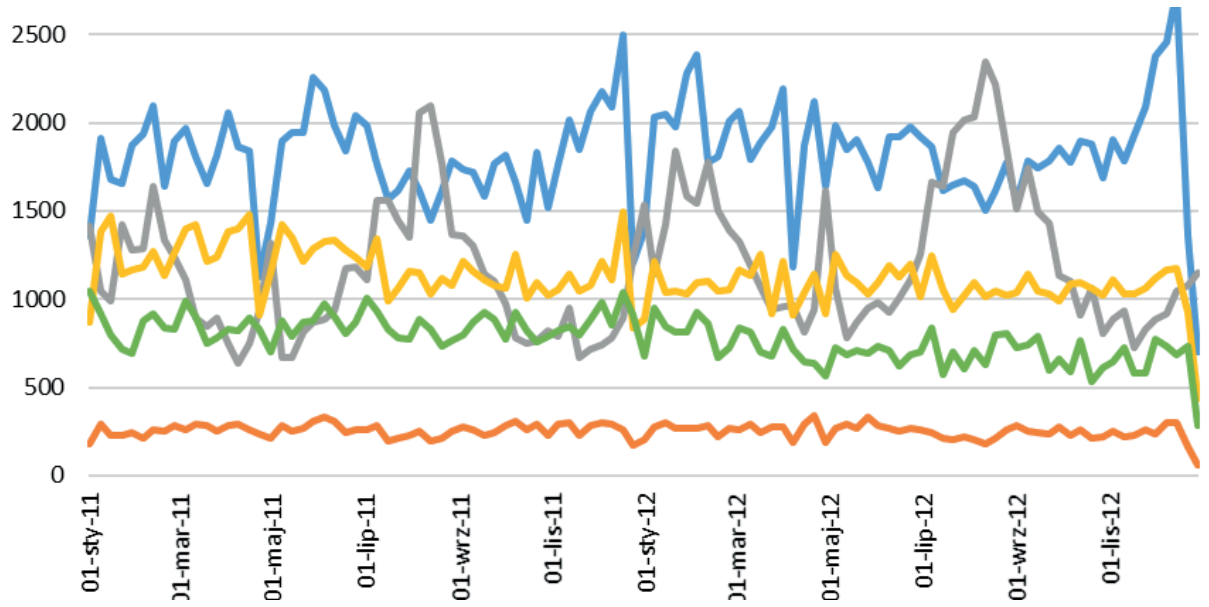

Rysunek 1. Szeregi czasowe liczby tygodniowych wypłat dla wybranych bankomatów Źródło: opracowanie własne na podstawie danych uzyskanych od operatora sieci

Wstępna analiza szeregów wypłat z Rysunku 1 nasuwa wniosek o znacznym zróżnicowaniu w liczbie wypłat w grupie wybranych bankomatów. Liczba wypłat z bankomatu 1, który jest zlokalizowany w centrum handlowym, podlega dość dużym wahaniom w wybranym okresie. Jednak w zdecydowanej większości oscyluje ona w przedziale 1500-2000, co daje średnio około 250 wypłat dziennie. Również duże wahania występują w szeregu czasowym liczby wypłat z bankomatu 3 . W tym przypadku występujące wahania mają charakter sezonowy (bankomat zlokalizowany jest w Zakopanem). Liczba wypłat najczęściej mieści się w przedziale 1000-1500, co daje średnio około 170 wypłat dziennie. Dla pozostałych bankomatów liczba wypłat jest niższa. Dotyczy to zwłaszcza bankomatu 2, dla którego jest to około 250 wypłat tygodniowo, czyli średnio 30-40 na dzień. Dla bankomatów o najniższej liczbie wypłat również wahania wydają się znacznie mniejsze.

Wnioski, które zostały wysunięte z analizy szeregów czasowych, znajdują potwierdzenie w analizie wykresów pudełkowych zamieszczonych na Rysunku 2. Najwyższa średnia liczba wypłat miała miejsce w przypadku bankomatu 1 i wynosiła ona ponad 260 wypłat na dzień. Dla bankomatów 3 i 4 ta wartość kształtowała się na poziomie 160-170 wypłat. Najmniej wypłat (około 40 na dzień) dokonywano w bankomacie w oddziale bankowym. Analizując Rysunki 1 i 2 pod względem zróżnicowania liczby wypłat w bankomacie, można zauważyć, iż największe zróżnicowanie występuje dla bankomatu 3 oraz dla bankomatu 1. Dla bankomatu 3 rozstęp ćwiartkowy wynosi około 100, a dla bankomatu 3 około 60. Dodatkowo w bankomatach 1 i 4 występuje znaczna liczba danych odstających.

Z perspektywy zarządcy, dla którego liczba wypłat wiąże się bezpośrednio z zyskami, największe dochody przynosi bankomat 1. Przeciętny dzienny zysk związany z opłatami interchange dla tego bankomatu to około 400 zł (1,2 zł za jedną 
wypłatę). Dla porównania w przypadku bankomatu 2 jest to kwota nieco ponad 40 zł. Dodatkowo należy zwrócić uwagę, że o ile w bankomatach 2, 4 i 5 liczba wypłat w kolejnych tygodniach nie podlega dużym wahaniom, to dla bankomatów 1 oraz 3 nie w każdym tygodniu można oczekiwać liczby wypłat na tym samym poziomie.

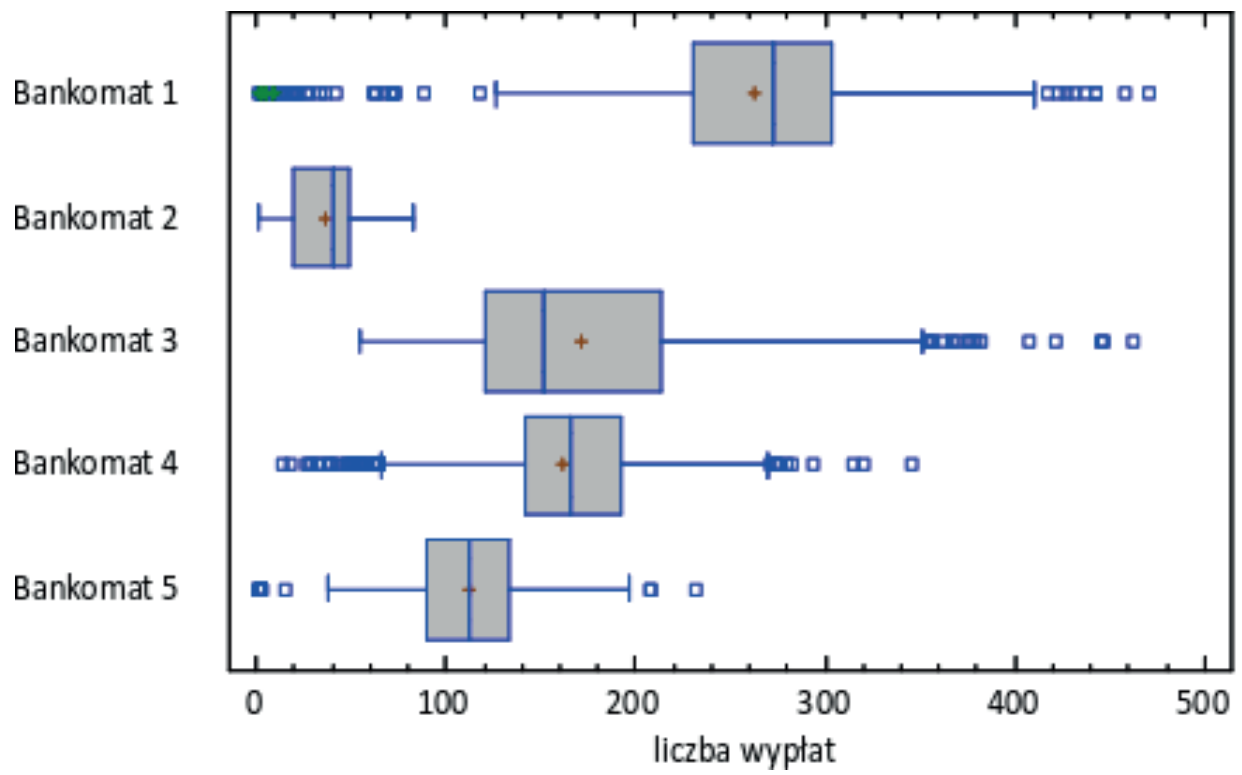

Rysunek 2. Wykres pudełkowy dla dziennej liczby wypłat w wybranych bankomatach Źródło: opracowanie własne na podstawie danych uzyskanych od operatora sieci

Największe względne zróżnicowanie w liczbie wypłat występuje dla bankomatów 2 i 3. Dodatkowo dla bankomatu w Zakopanem zauważalne jest występowanie sezonowości w liczbie wypłat (por. Rysunek 2). Jest to dość naturalne w przypadku miejscowości turystycznej. Na podstawie analizy liczby wypłat, która bezpośrednio przekłada się na dochód firmy zarządzającej, najkorzystniej wypada zatem bankomat 1 , a następnie bankomaty 3 i 4. Zdecydowanie najmniej opłacalny w analizowanym kontekście jest bankomat 2.

Kolejna analiza dotyczyła wielkości wypłat w poszczególnych bankomatach. Jak wspomniano we wstępie, wielkość wypłat przekłada się bezpośrednio na koszty, jakie ponosi operator sieci, związane z „mrożeniem” gotówki i jej transportem. Wstępna analiza szeregów czasowych wielkości tygodniowych wypłat dla wybranych bankomatów (por. Rysunek 3) prowadzi do wniosku, iż liczba wypłat przekłada się bezpośrednio na wielkość wypłat. Najwięcej gotówki jest wypłacane z bankomatów 1 i 3 - są to wypłaty rzędu ponad 500 tys. zł tygodniowo. Dla bankomatu 3 zauważalne jest występowanie sezonowości. Różnica w wielkości 
tygodniowych wypłat w tym bankomacie sięga rzędu 700 tys. zł (dla kwietnia 2011 i stycznia 2012 roku). Dla bankomatu 1 również występują wahania w wielkości wypłat, ale nie o aż tak dużej amplitudzie. Dla pozostałych bankomatów wielkość wypłat jest znacznie niższa i mają one mniejsze wahania. Najmniej gotówki pobierane jest $\mathrm{z}$ bankomatu w oddziale bankowym i jest to wielkość rzędu 100 tys. zł w tygodniu.

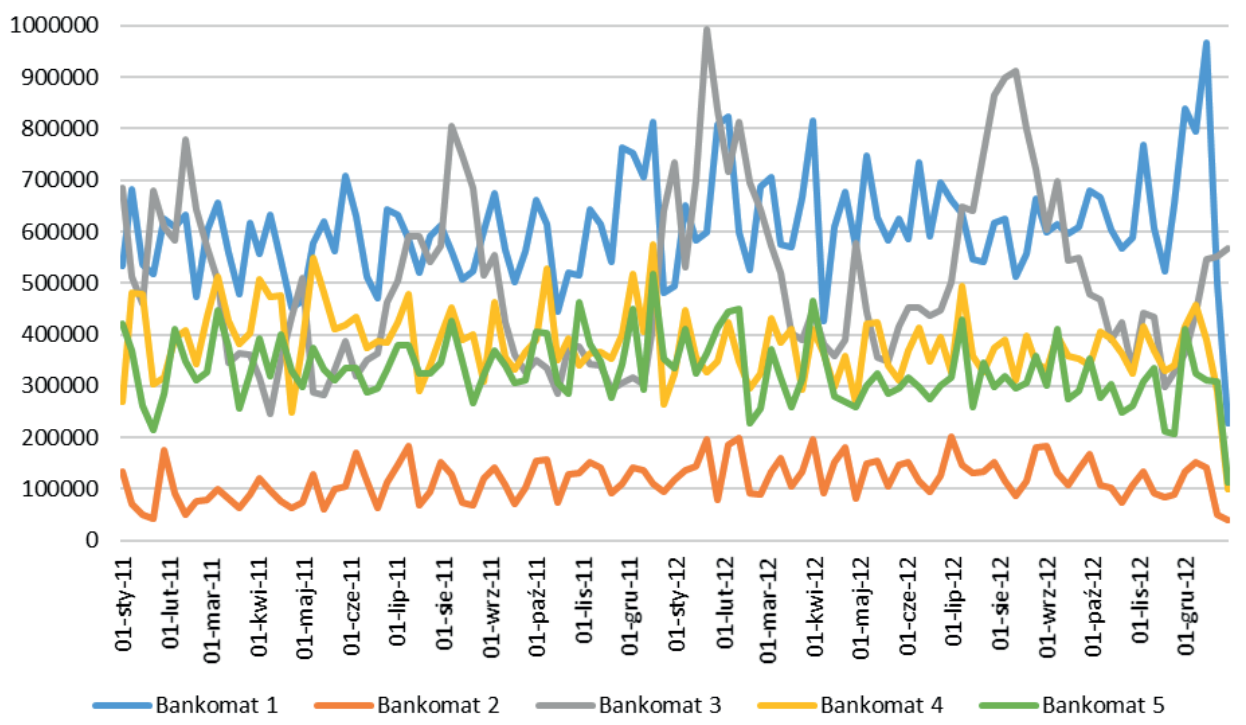

Rysunek 3. Szeregi czasowe wielkości tygodniowych wypłat dla wybranych bankomatów Źródło: opracowanie własne na podstawie danych uzyskanych od operatora sieci

Analogicznie jak dla liczby wypłat wykonano wykresy pudełkowe dla wielkości dziennych wypłat z poszczególnych bankomatów.

Również i w tym przypadku wnioski wyciągnięte na podstawie analizy szeregów czasowych potwierdzają się w pełni. Z Rysunku 4 odczytujemy, że przeciętnie największe kwoty wypłaca się z bankomatów 1 oraz 3 . Statystycznie każdego dnia z tych bankomatów wypłaca się około 80 tys. zł. Dla porównania w pozostałych bankomatach są to, odpowiednio, wielkości rzędu 50 tys. i 20 tys. złotych. Na wykresach pudełkowych zauważalne jest również duże zróżnicowanie wielkości wypłat dla bankomatów 1 i 3 . Na uwagę zwraca fakt, iż we wszystkich bankomatach występuje duża liczba danych odstających. Są to wypłaty o wartościach znacznie przewyższających średnie wypłaty dla poszczególnych bankomatów. Występowanie takich wypłat jest niekorzystne dla operatora, gdyż wiąże się z ryzykiem nieprzewidywalnego braku gotówki w bankomacie, a w konsekwencji niezadowolenia klientów.

W celu dokładniejszej analizy struktury wypłat w Tabeli 3 zamieszczono podstawowe statystyki dla liczby i wielkości wypłat. Dodatkowo przedstawiono 
średnią wartość pojedynczej dziennej wypłaty oraz współczynnik korelacji dla liczby i wielkości wypłat. Pierwsza z wielkości może być jednym z wyznaczników opłacalności funkcjonowania bankomatu. Im mniejsza wartość pojedynczej wypłaty, tym mniejsze koszty obsługi w przeliczeniu na liczbę operacji. Druga miara, czyli współczynnik korelacji dla liczby wielkości wypłat w ciągu dnia, pozwoli na stwierdzenie, czy istnieje zależność liniowa pomiędzy wielkością wypłat a liczbą wypłat. Wyższa wartość współczynnika korelacji oznacza, że wielkości wypłat bezpośrednio zależą od liczby wypłat.

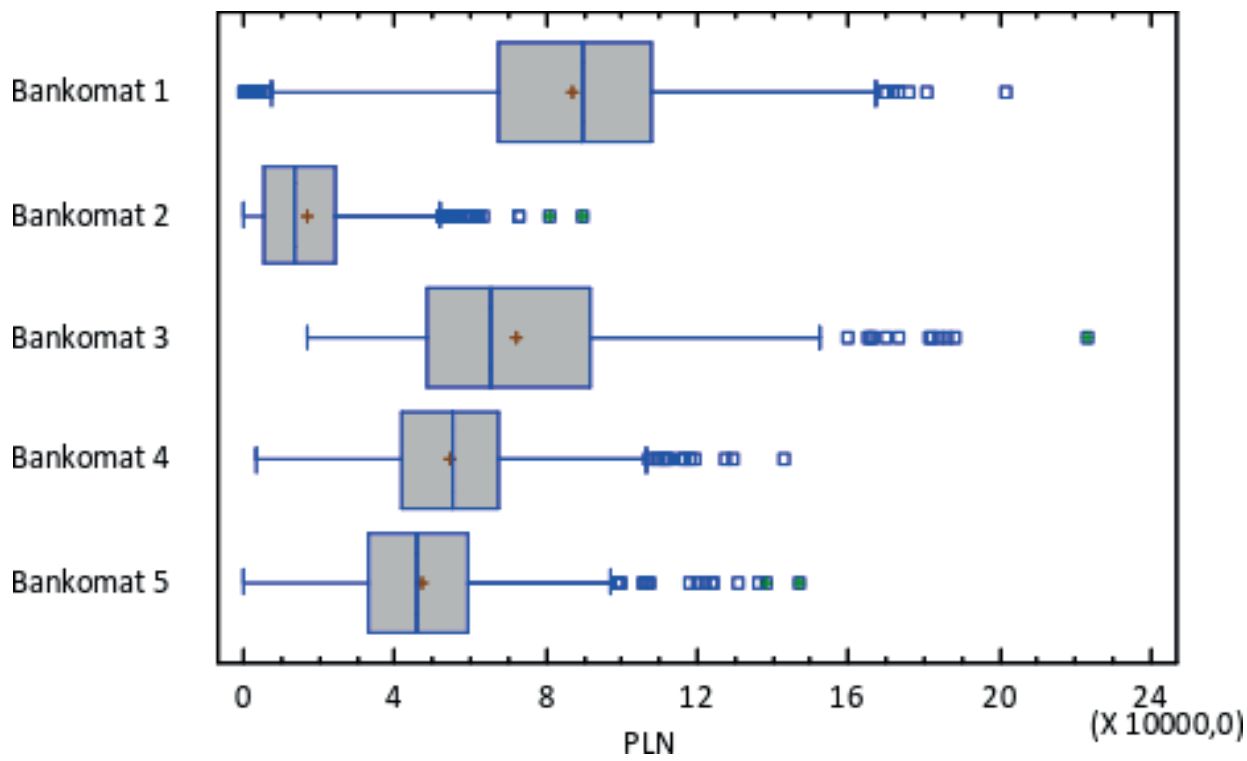

Rysunek 4. Wykres pudełkowy dla dziennej wielkości wypłat w wybranych bankomatach

Źródło: opracowanie własne na podstawie danych uzyskanych od operatora sieci

Tabela 3. Podstawowe statystyki dziennych wielkości wypłat z pięciu wybranych bankomatów

\begin{tabular}{|l|c|c|c|c|c|c|c|}
\hline \multirow{2}{*}{$\begin{array}{c}\text { Numer } \\
\text { bankomatu }\end{array}$} & \multicolumn{2}{|c|}{$\begin{array}{c}\text { Liczba dziennych } \\
\text { wyplat }\end{array}$} & \multicolumn{2}{|c|}{$\begin{array}{c}\text { Wielkość dziennych } \\
\text { wyplat }\end{array}$} & \multicolumn{2}{|c|}{$\begin{array}{c}\text { Srednia wielkość } \\
\text { dziennej wyplaty }\end{array}$} & Wspól- \\
\cline { 2 - 7 } & $\begin{array}{c}\text { Śred- } \\
\text { nia }\end{array}$ & $\begin{array}{c}\text { Współczyn- } \\
\text { nik zmien- } \\
\text { ności [\%] }\end{array}$ & $\begin{array}{c}\text { Średnia } \\
\text { [PLN] }\end{array}$ & $\begin{array}{c}\text { Wspólczyn- } \\
\text { nik zmien- } \\
\text { ności [\%] }\end{array}$ & $\begin{array}{c}\text { Śred- } \\
\text { nia } \\
\text { [PLN] }\end{array}$ & $\begin{array}{c}\text { Wspólczyn- } \\
\text { nik zmien- } \\
\text { ności [\%] }\end{array}$ & $\begin{array}{c}\text { korela- } \\
\text { cji }\end{array}$ \\
\hline Bankomat 1 & 262,05 & 29,40 & 87202,80 & 38,49 & 325,32 & 22,50 & 0,87 \\
\hline Bankomat 2 & 36,36 & 49,26 & 16805,00 & 87,68 & 408,66 & 65,95 & 0,72 \\
\hline Bankomat 3 & 170,96 & 40,32 & 72374,50 & 43,75 & 424,68 & 21,08 & 0,88 \\
\hline Bankomat 4 & 161,96 & 31,79 & 54774,40 & 42,36 & 330,53 & 24,93 & 0,83 \\
\hline Bankomat 5 & 111,76 & 31,36 & 47427,56 & 46,03 & 414,58 & 32,35 & 0,77 \\
\hline
\end{tabular}

Źródło: opracowanie własne na podstawie danych uzyskanych od operatora sieci 
Analizując wyniki dotyczące średniej pojedynczej wypłaty zamieszczone w Tabeli 3, zauważamy, iż średnie dzienne wypłaty są najwyższe dla bankomatów 2,3 oraz 5 . Średnia z tych średnich kształtuje się na poziomie nieco powyżej 400 zł. Jednak znacznie wyższe zróżnicowanie wśród średnich jest w przypadku bankomatu 2. Współczynnik zmienności dla niego wynosi około $65 \%$, a dla porównania w bankomacie 3 kształtuje się na poziomie nieco ponad $20 \%$. Dla bankomatów 1 i 4 zarówno średnia dzienna wypłata, jak i jej zmienność są zbliżone i kształtują się odpowiednio na poziomie 330 zł i $22-24 \%$. Na tym etapie analizy możemy zatem wnioskować, iż z pięciu wybranych bankomatów mniejsze koszty związane z „mrożeniem” gotówki względem liczby wypłat generują bankomaty 1 i 4 .

Wartości współczynników korelacji dla wszystkich bankomatów wskazują na silną zależność pomiędzy wielkością i liczbą dziennych wypłat. Na tej podstawie nie można zatem jednoznacznie stwierdzić, iż w którymś z bankomatów występuje znacznie większa liczba danych odstających, związanych z wielkością wypłat.

Podsumowując tę część analizy, można zauważyć, iż największy zysk z usług bankomatowych uzyskuje się w przypadku bankomatu 1, zlokalizowanego w centrum handlowym w Krakowie. W tym bankomacie jest dużo wypłat o stosunkowo niedużej wartości (relatywnie niska średnia pojedynczej wypłaty). Natomiast wśród wybranych bankomatów najgorzej wypada bankomat 2 w Rzeszowie, zlokalizowany w oddziale bankowym. W tej maszynie jest niewiele wypłat, a średnia pojedynczej wypłaty jest względnie wysoka.

W procesie zarządzania siecią bankomatową ważne jest zapewnienie dostępności gotówki w każdym bankomacie przez cały okres jego funkcjonowania. Aby to było możliwe, należy dokonywać trafnych przewidywań wielkości wypłat z danego bankomatu na kilka lub kilkanaście dni do przodu. Aby prognoza mogła być dostatecznie dokładna, konieczne jest, aby dla danego bankomatu wielkość pojedynczej wypłaty oraz liczba tych wypłat były w miarę stabilne. Częste występowanie dużych, niespodziewanych wypłat negatywnie wpływa na jakość predykcji. Może to skutkować niedoszacowaniem prognozy i koniecznością wykonania doładunku bankomatu w trybie ekspresowym, który jest bardzo kosztowny. Brak dostępności gotówki w bankomacie może też być źródłem niezadowolenia klienta i spowodować, że następnym razem wybierze bankomat z innej sieci.

W tym kontekście interesująca może okazać się analiza struktury wielkości wypłat z poszczególnych bankomatów. Na Rysunku 5 zilustrowano rozkłady wielkości wypłat dla poszczególnych bankomatów.

Analizując Rysunek 5, zauważamy, iż dla bankomatów 1 oraz 2 wypłaty do $100 \mathrm{zł}$ stanowią ponad połowę wszystkich wypłat. W przypadku bankomatu 4-procentowy udział wypłat do $100 \mathrm{zł} \mathrm{i} \mathrm{do} 1000 \mathrm{zł}$ jest zbliżony. Natomiast dla bankomatów 3 i 5 większość wypłat mieści się w przedziale 100-1000 zł. Trzeba 
dodać, że dla bankomatu 3 wypłat z grupy 2 jest blisko dwukrotnie więcej niż tych z grupy 1 . Dla wszystkich bankomatów wypłaty ponad 1000 zł stanowiły nieduży odsetek. Tylko dla bankomatu 2 przekraczał on $10 \%$.

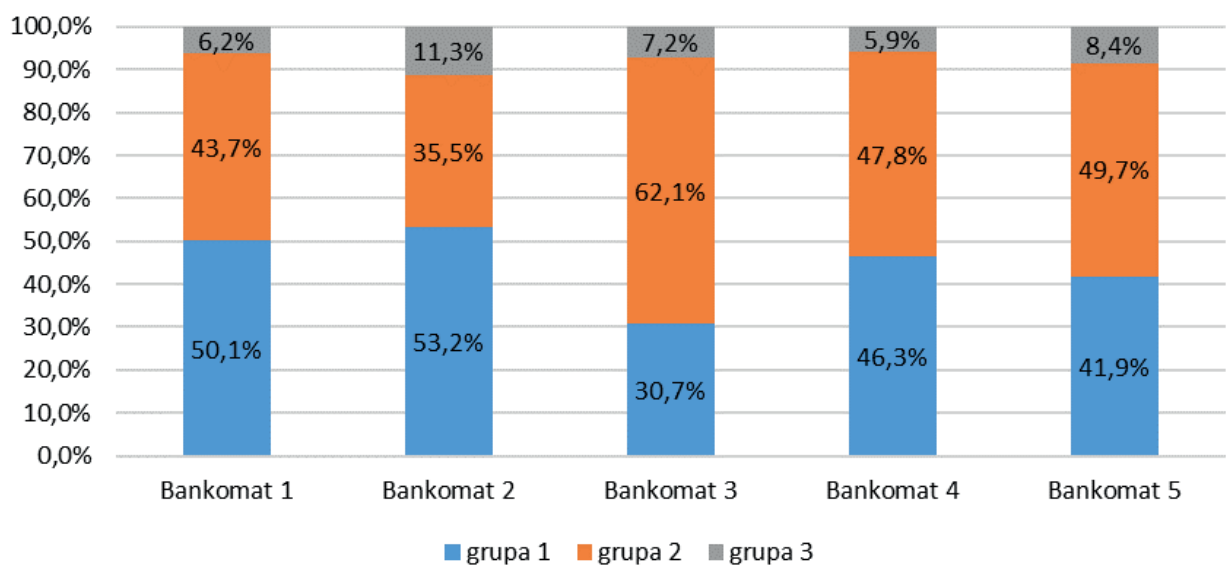

Rysunek 5. Rozkład wielkości wypłat dla wybranych bankomatów

Źródło: opracowanie własne na podstawie danych uzyskanych od operatora sieci

Analiza rozkładu wielkości wypłat dla pięciu wybranych bankomatów potwierdziła wcześniej wysunięte wnioski. W bankomacie 1 najwięcej wypłat stanowią wypłaty do 100 zł, a wypłat powyżej 1000 zł jest niewiele ponad 6\%. W bankomacie 4 liczba niskich i średnich wypłat jest zbliżona, a odsetek wysokich wypłat jest niski, dlatego można oczekiwać, że zyski z tego bankomatu są porównywalnie wyższe niż dla bankomatów 3 i 4, gdzie średnie wypłaty znacznie przewyższają te niskie. W bankomacie 2 wypłat niskich jest najwięcej, jednak to, co sprawia, iż ten bankomat jest najmniej rentowny, to fakty częstszego niż w innych bankomatach występowania wypłat wysokich.

\section{Wyniki empiryczne dla wybranych rodzajów lokalizacji}

W tej części artykułu zostaną przedstawione wyniki analizy struktury wypłat $\mathrm{z}$ bankomatów w ramach wybranych grup bankomatów. Grupowanie bankomatów przeprowadzono na podstawie dwóch kryteriów, tj. typu lokalizacji oraz kategorii dostępności, które zostały opisane w punkcie 2 . 


\subsection{Wyniki analizy dla bankomatów w poszczególnych typach lokalizacyjnych}

Analiza liczby i wielkości wypłat z pięciu wybranych bankomatów wykazała, iż występuje zróżnicowanie w strukturze wypłat w bankomatach o różnych typach lokalizacji. Jak już wspomniano, struktura wypłat ma bezpośredni wpływ na opłacalność funkcjonowania bankomatów. Jednak analiza ta dla wybranych bankomatów nie stanowi dowodu na występowanie ogólnych prawidłowości związanych z opłacalnością funkcjonowania i stabilnością rodzaju wypłat bankomatów w poszczególnych typach lokalizacji. Aby zweryfikować hipotezę, iż typ lokalizacji ma wpływ na strukturę wypłat oraz dokonać próby wskazania typów lokalizacji, które przynoszą największe korzyści z funkcjonowania, zbadano wszystkie 217 bankomatów podzielonych według typów lokalizacji i kategorii miejscowości. Analiza została przeprowadzona na średnich wartościach poszczególnych wielkości dla każdego z bankomatów.

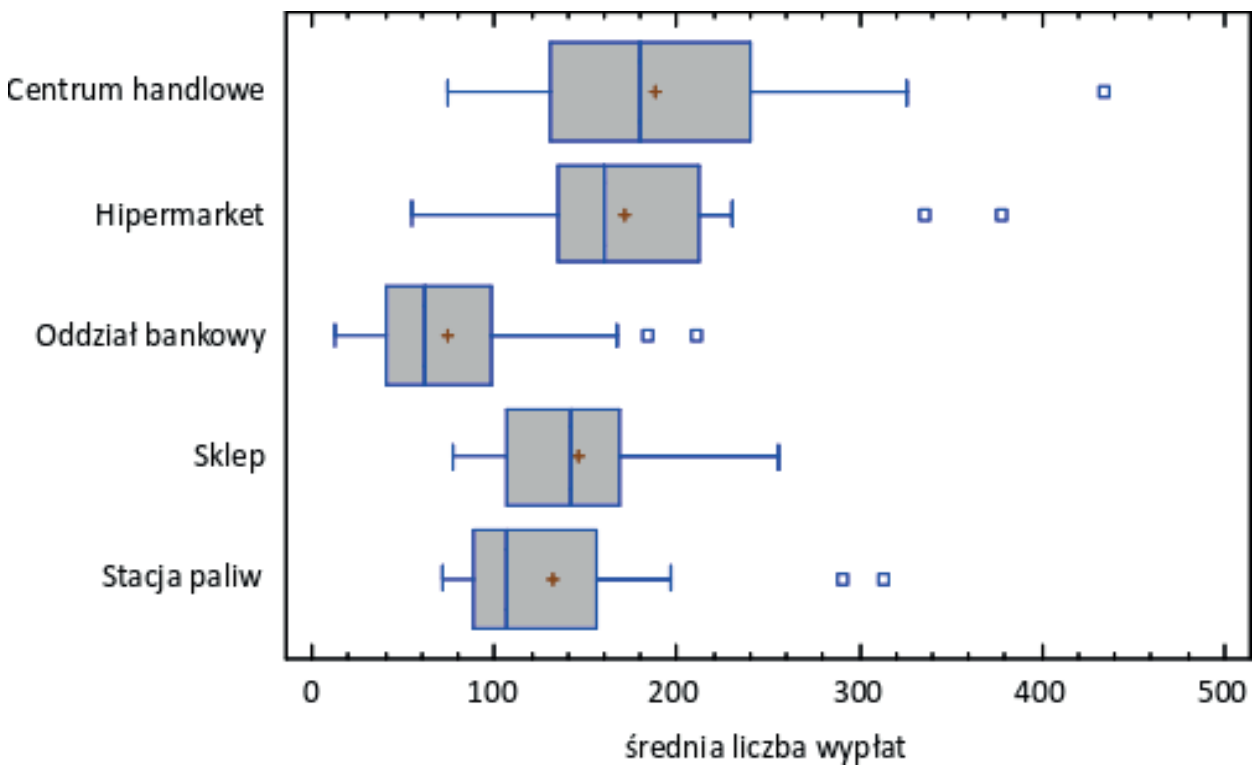

Rysunek 6. Wykresy pudełkowe dla średnich dziennych liczb wypłat z bankomatu w zależności od typu lokalizacji

Źródło: opracowanie własne na podstawie danych uzyskanych od operatora sieci

Analizując uzyskane wyniki zamieszczone na Rysunku 6 i w Tabeli 4, można zauważyć, iż pomiędzy poszczególnymi lokalizacjami występuje zróżnicowanie w strukturze wypłat. Dotyczy to zwłaszcza średniej dziennej liczby wypłat. Największą średnią liczbę wypłat notuje się dla bankomatów w centrach handlowych oraz hipermarketach. Są to liczby wypłat na poziomie 170-180 dziennie. 
Przeciętnie najmniej wypłat notuje się w oddziałach bankowych - jest to wartość poniżej 75 wypłat na dzień. Wyniki przeprowadzonego testu Kruskala-Wallisa potwierdzają istotność w zróżnicowaniu pomiędzy średnimi liczbami wypłat dla poszczególnych typów lokalizacji ( $p$-value $=0,000$ ).

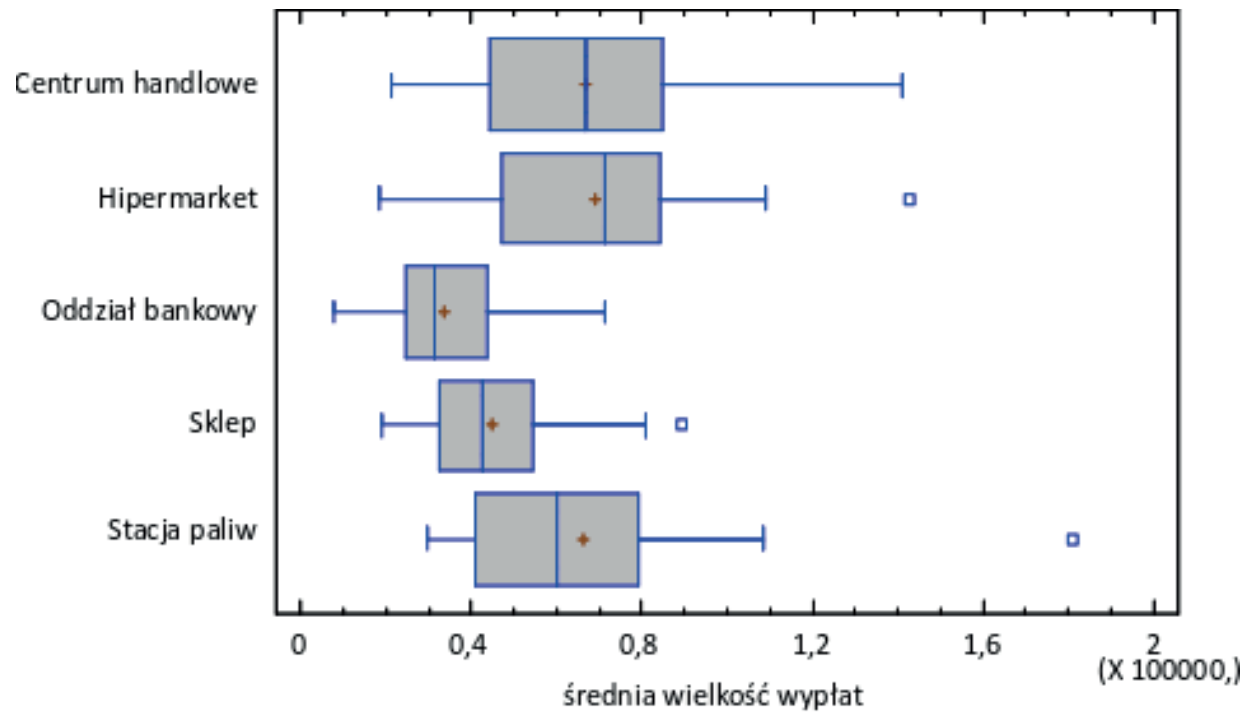

Rysunek 7. Wykresy pudełkowe dla średnich dziennych wielkości wypłat z bankomatu w zależności od typu lokalizacji

Źródło: opracowanie własne na podstawie danych uzyskanych od operatora sieci

Tabela 4. Podstawowe statystyki dziennych wielkości wypłat z bankomatu dla średnich wartości w poszczególnych typach lokalizacji

\begin{tabular}{|c|c|c|c|c|c|c|c|}
\hline \multirow{2}{*}{$\begin{array}{l}\text { Typ lokali- } \\
\text { zacji }\end{array}$} & \multicolumn{2}{|c|}{$\begin{array}{c}\text { Średnia liczba } \\
\text { dziennych wypłat }\end{array}$} & \multicolumn{2}{|c|}{$\begin{array}{l}\text { Średnia wielkość } \\
\text { dziennych wypłat }\end{array}$} & \multicolumn{2}{|c|}{$\begin{array}{l}\text { Średnia ze średnich } \\
\text { wielkości pojedyn- } \\
\text { czej wypłaty }\end{array}$} & \multirow{2}{*}{$\begin{array}{c}\text { Średnia } \\
\text { wartość } \\
\text { wspól- } \\
\text { czyn- } \\
\text { nika } \\
\text { korelacji }\end{array}$} \\
\hline & $\begin{array}{c}\text { Śred- } \\
\text { nia }\end{array}$ & $\begin{array}{c}\text { Współczyn- } \\
\text { nik zmien- } \\
\text { ności [\%] }\end{array}$ & $\begin{array}{l}\text { Średnia } \\
\text { [PLN] }\end{array}$ & $\begin{array}{c}\text { Współczyn- } \\
\text { nik zmien- } \\
\text { ności [\%] }\end{array}$ & $\begin{array}{c}\text { Śred- } \\
\text { nia } \\
{[\mathrm{PLN}]}\end{array}$ & $\begin{array}{c}\text { Współczyn- } \\
\text { nik zmien- } \\
\text { ności [\%] }\end{array}$ & \\
\hline $\begin{array}{l}\text { Centrum } \\
\text { handlowe }\end{array}$ & 188,5 & 41,0 & 67045,1 & 42,51 & 345,4 & 23,1 & 0,87 \\
\hline Hipermarket & 171,8 & 37,4 & 68781,5 & 39,30 & 388,9 & 29,9 & 0,88 \\
\hline $\begin{array}{l}\text { Oddział } \\
\text { bankowy }\end{array}$ & 73,9 & 57,2 & 33656,7 & 40,66 & 489,3 & 42,2 & 0,84 \\
\hline Sklep & 146,5 & 32,4 & 44948,9 & 37,72 & 298,2 & 23,9 & 0,87 \\
\hline Stacja paliw & 131,3 & 47,1 & 66346,3 & 47,79 & 494,1 & 20,6 & 0,85 \\
\hline
\end{tabular}

Źródło: opracowanie własne na podstawie danych uzyskanych od operatora sieci 
Wyniki analizy dla wielkości wypłaty (por. Rysunek 7 i Tabelę 4) w poszczególnych typach lokalizacyjnych również wskazują na zróżnicowanie w średniej wielkości przeciętnych wypłat. Średnio najwięcej gotówki dziennie jest wypłacane $\mathrm{z}$ bankomatów zlokalizowanych $\mathrm{w}$ centrach handlowych, hipermarketach i na stacjach paliw. Wartość ta wynosi ponad 65 tys. zł i jest dwukrotnie większa od tej, jaką uzyskano dla bankomatów zlokalizowanych w bankach. Przeprowadzona analiza wariancji potwierdziła istotność zróżnicowania średniej pojedynczej wypłaty w poszczególnych grupach lokalizacyjnych. Również w tym przypadku test Kruskala-Wallisa wskazał na istotne zróżnicowanie w grupie średnich wielkości wypłat dla poszczególnych typów lokalizacji $(p$-value $=0,000)$.

Analiza średniej liczby wypłat zamieszczonych w Tabeli 4 w poszczególnych typach lokalizacji wskazuje na znaczące zróżnicowanie tych średnich dla bankomatów w poszczególnych grupach. Wartość współczynników zmienności kształtuje się na poziomie umiarkowanym lub wysokim. Występują też dane odstające, wskazujące na znacznie większą przeciętną liczbę wypłat w porównaniu z całą grupą. Podobne zróżnicowanie wykazują średnie wielkości wypłat dla poszczególnych typów lokalizacji.

Podsumowując powyższą analizę, można stwierdzić, iż z perspektywy zarządcy korzystnymi lokalizacjami bankomatów są centra handlowe, hipermarkety oraz sklepy. W pierwszych dwóch typach lokalizacji zanotowano relatywnie wysoką liczbę wypłat przy średniej wielkości pojedynczych wypłat na poziomie poniżej 400 zł. Z kolei wypłat w sklepach jest nieco mniej niż we wspomnianych lokalizacjach, jednak znacznie mniejsza jest ich średnia wartość. Kształtuje się ona na poziomie poniżej 300 zł. Funkcjonowanie bankomatów w pozostałych typach lokalizacji (tj. w oddziałach bankowych oraz na stacjach paliw), w związku z wysoką średnią dla pojedynczej wypłaty oraz niską lub średnią liczbą wypłat, wykazuje mniejszą opłacalność.

Aby uzyskać pełniejszy obraz struktury wypłat (zarówno ze względu na wielkości, jak i liczbę) na Rysunku 8 przedstawiono rozkład wielkości wypłat z podziałem na poszczególne grupy w analizowanych typach lokalizacji.

Analizując wykresy przedstawione na Rysunku 8, można zauważyć, iż w przypadku tylko jednej lokalizacji, tj. sklepów, liczba najniższych wypłat, czyli do 100 zl, stanowi ponad $50 \%$ wszystkich wypłat. Natomiast w przypadku bankomatów zlokalizowanych w hipermarketach większość stanowią wypłaty średnie, czyli z grupy 2. Stosunkowo dużo średnich wypłat występuje również na stacjach paliw. W tej lokalizacji wypłaty średnie stanowią blisko $50 \%$ wypłat, a wypłaty niskie niewiele ponad 38\%. Ze wszystkich typów lokalizacji w dwóch z nich, tj. oddziale bankowym i na stacji paliw, liczba wypłat $1000 \mathrm{zł}$ i więcej przekracza $10 \%$. Jest to również potwierdzenie wniosków dotyczących opłacalności funkcjonowania bankomatów w poszczególnych typach lokalizacji, wysuniętych na podstawie wcześniejszych badań. 


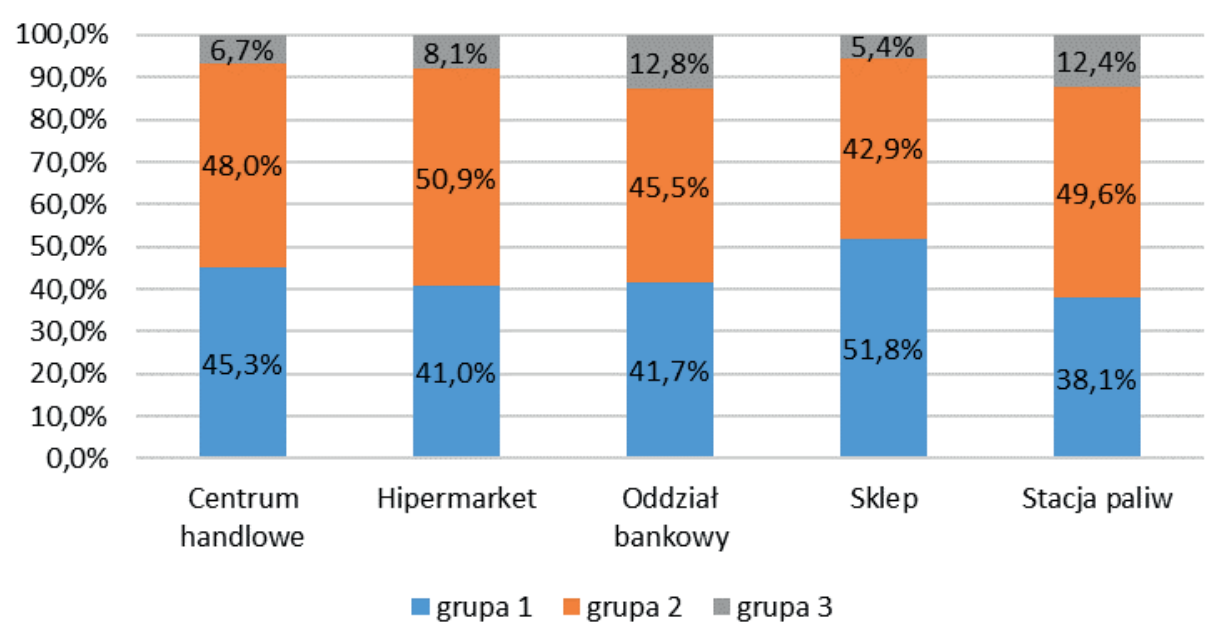

Rysunek 8. Struktura wielkości pojedynczych wypłat w wybranych typach lokalizacji Źródło: opracowanie własne na podstawie danych uzyskanych od operatora sieci

Możemy stwierdzić, iż istnieją pewne ogólne tendencje związane z własnościami wypłat $\mathrm{z}$ bankomatów w poszczególnych typach lokalizacyjnych. Mogą one stanowić przesłanki dla operatora o opłacalności instalowania bankomatów w poszczególnych lokalizacjach. Przykładowo: z analizy wynika, że najkorzystniejsze jest instalowanie bankomatów w centrach handlowych, ponieważ jest tam najwięcej wypłat o stosunkowo niewielkiej średniej wartości. Natomiast najmniej opłacalna lokalizacja dla bankomatu to oddział bankowy. Dodatkowo uzyskane informacje mogą stanowić podstawę przy budowaniu modeli prognostycznych.

\subsection{Wyniki analizy dla bankomatów w poszczególnych kategoriach ich dostępności}

Poprzednia analiza wykazała, iż typ lokalizacji istotnie różnicuje strukturę wypłat $\mathrm{z}$ bankomatów. Jednak okazało się również, że struktura w obrębie bankomatów z tej samej lokalizacji również może się różnić. Jedną z przyczyn takiego stanu rzeczy może być fakt, iż bankomaty są zlokalizowane w tym samym otoczeniu, jednak w miejscowościach o różnym zapotrzebowaniu na gotówkę. W związku z tym kolejna analiza dotyczyła sprawdzenia, czy struktura wypłat jest uwarunkowana przez miejscowość, w jakiej dany bankomat się znajduje, a konkretnie przez to, jaka jest dostępność bankomatu w danej miejscowości.

W Tabeli 5 oraz na Rysunkach 9-10 zamieszczono wyniki analizy dotyczącej liczby wypłat i średniej pojedynczej wypłaty w poszczególnych kategoriach dostępności bankomatu. 


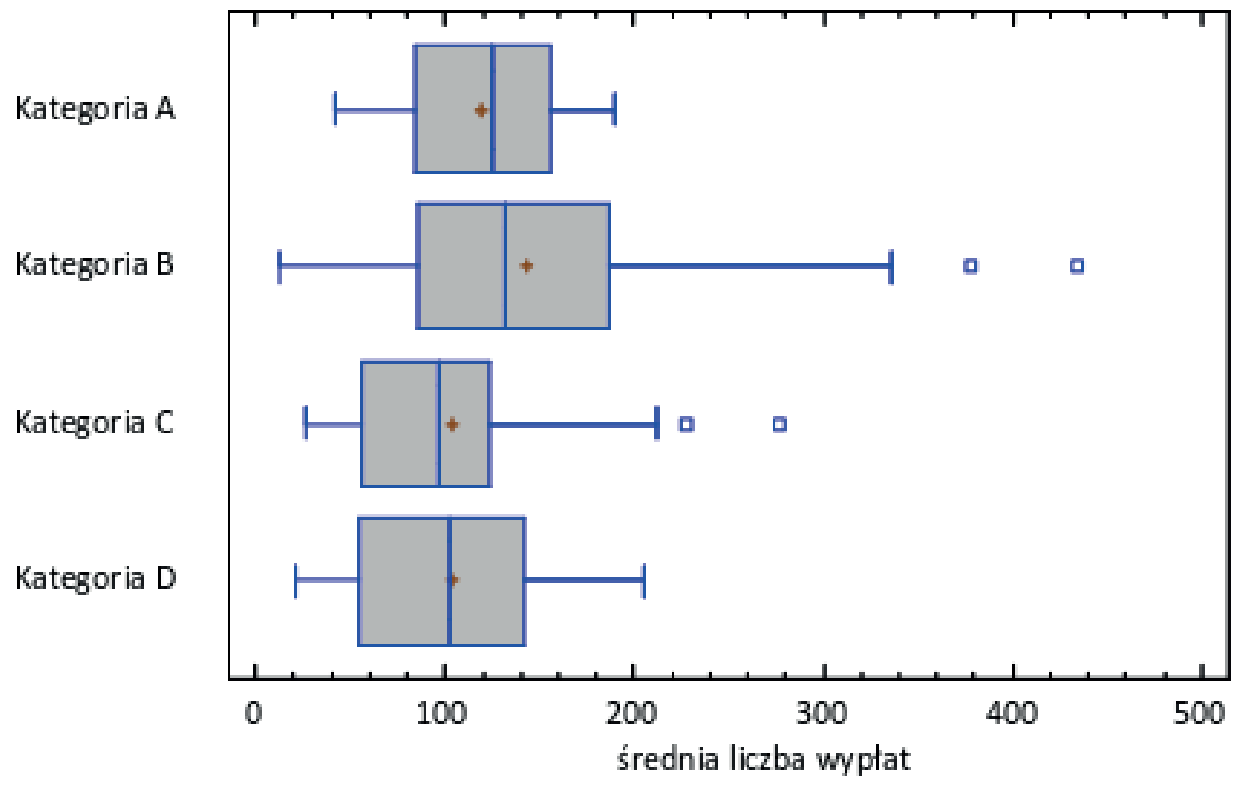

Rysunek 9. Wykresy pudełkowe dla średnich liczb dziennych wypłat z bankomatu w zależności od kategorii dostępności

Źródło: opracowanie własne na podstawie danych uzyskanych od operatora sieci

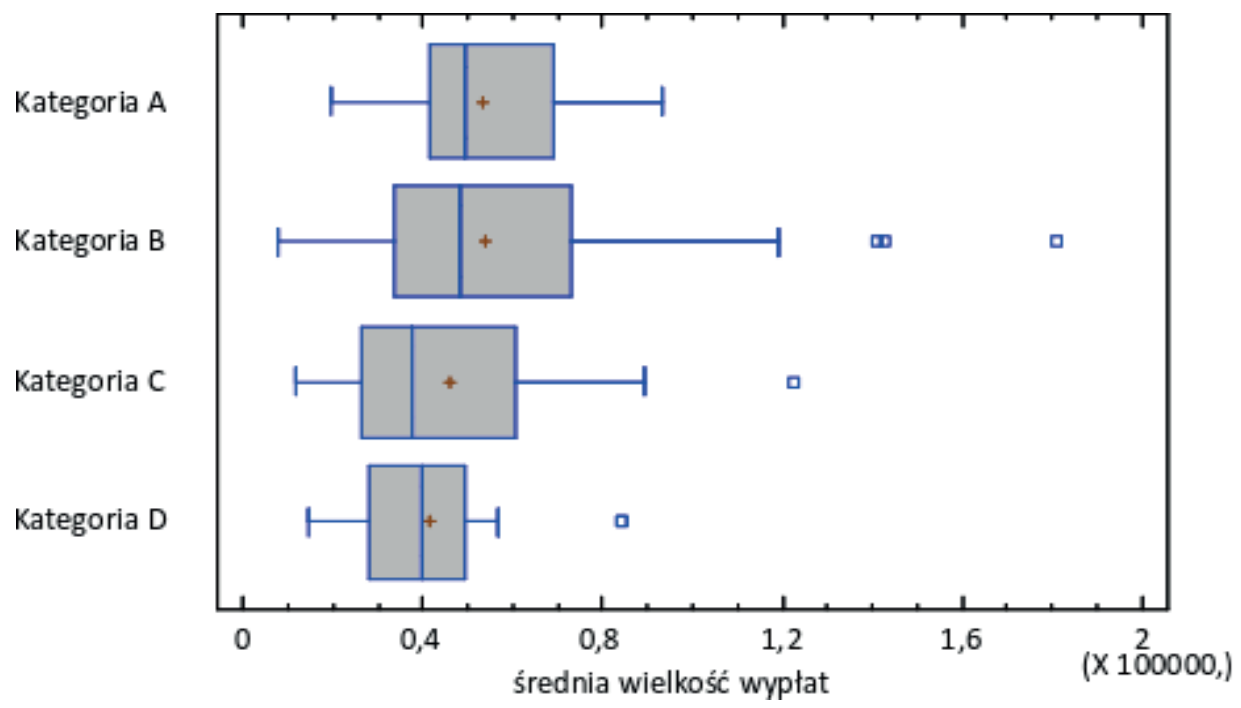

Rysunek 10. Wykresy pudełkowe dla średnich dziennych wypłat z bankomatu w zależności od kategorii dostępności

Źródło: opracowanie własne na podstawie danych uzyskanych od operatora sieci 
Tabela 5. Podstawowe statystyki dziennych wielkości dla średnich wartości wypłat w poszczególnych kategoriach dostępności

\begin{tabular}{|c|c|c|c|c|c|c|c|}
\hline \multirow{2}{*}{$\begin{array}{c}\text { Kategoria } \\
\text { dostępności }\end{array}$} & \multicolumn{2}{|c|}{$\begin{array}{c}\text { Średnia liczba } \\
\text { dziennych wyplat }\end{array}$} & \multicolumn{2}{|c|}{$\begin{array}{l}\text { Średnia wielkość } \\
\text { dziennych wypłat }\end{array}$} & \multicolumn{2}{|c|}{$\begin{array}{c}\text { Średnia ze średnich } \\
\text { wielkości pojedyn- } \\
\text { czej wypłaty }\end{array}$} & \multirow{2}{*}{$\begin{array}{c}\text { Średnia } \\
\text { wartość } \\
\text { wspól- } \\
\text { czynnika } \\
\text { korelacji }\end{array}$} \\
\hline & $\begin{array}{l}\text { Śred- } \\
\text { nia }\end{array}$ & $\begin{array}{c}\text { Wspólczyn- } \\
\text { nik zmien- } \\
\text { ności [\%] }\end{array}$ & $\begin{array}{c}\text { Średnia } \\
{[\text { PLN] }}\end{array}$ & $\begin{array}{c}\text { Współczyn- } \\
\text { nik zmien- } \\
\text { ności [\%] }\end{array}$ & $\begin{array}{c}\text { Śred- } \\
\text { nia } \\
{[\text { PLN] }}\end{array}$ & $\begin{array}{l}\text { Współczyn- } \\
\text { nik zmien- } \\
\text { ności [\%] }\end{array}$ & \\
\hline Kategoria A & 119,1 & 38,1 & 53358,6 & 37,01 & 453,8 & 29,0 & 0,86 \\
\hline Kategoria B & 142,5 & 54,1 & 54022,3 & 53,23 & 395,8 & 41,9 & 0,86 \\
\hline Kategoria C & 103,2 & 62,2 & 45973,9 & 56,96 & 451,5 & 25,1 & 0,84 \\
\hline Kategoria D & 103,7 & 52,2 & 41411,8 & 44,37 & 434,9 & 45,5 & 0,84 \\
\hline
\end{tabular}

Źródło: opracowanie własne na podstawie danych uzyskanych od operatora sieci

W przypadku wyników dotyczących średniej liczby wypłat dla poszczególnych kategorii dostępności różnice w uzyskanych średnich nie są tak znaczące, jak miało to miejsce dla typów lokalizacji. Przeciętnie najwięcej wypłat dokonuje się w bankomatach zlokalizowanych w miejscowościach kategorii B. Taki wynik może być związany z tym, iż do tej kategorii należy Kraków. Paradoksalnie najmniej wypłat (niewiele ponad 100 dziennie) odnotowuje się w miejscowościach kategorii C i D, czyli w takich, gdzie przypada najwięcej osób na jeden bankomat. Wyniki testu Kruskala-Wallisa wskazują na statystyczną istotność w różnicach liczby wypłat dla poszczególnych kategorii $(p$-value $=0,01)$. Zróżnicowanie w poszczególnych grupach, wyrażone współczynnikiem zmienności, kształtuje się na poziomie umiarkowanym dla miast z kategorii A oraz wysokim dla pozostałych. Wyniki analizy wielkości wypłat zamieszczone na Rysunku 9 i w Tabeli 5 są analogiczne jak dla liczby wypłat, tzn. przeciętnie w ciągu całego dnia najwięcej wypłaca się w bankomatach w miejscowościach kategorii B, a najmniej w C i D. W tym jednak przypadku test Kruskala-Wallisa nie wskazuje na istotność różnicy pomiędzy medianami wielkości wypłat $(p$-value $=0,12)$. Dokonując analizy średniej pojedynczej wypłaty (por. Tabela 5), stwierdzono, że przeciętnie najmniej (poniżej $400 \mathrm{zł}$ ) wypłaca się w miejscowościach kategorii B. W pozostałych kategoriach miejscowości wypłaca się przeciętnie około 440-460 zł.

Na Rysunku 11 przedstawiono rozkład wypłat z bankomatów w poszczególnych grupach miejscowości, z którego można odczytać, iż dla poszczególnych kategorii wartość średniego odsetka wypłat wysokich jest zbliżona (jest to wartość około $10 \%$ ). Pewne zróżnicowanie występuje w przypadku pozostałych wielkości wypłat. I tak dla miejscowości z kategorii A oraz C zdecydowanie największy odsetek stanowią wypłaty średnie. Jest to wartość ponad 50\% przy około 36-38\% wypłat niskich. Również w miejscowościach kategorii D przeważają wypłaty średnie. Jedynie w miejscowościach z kategorii B uzyskano bardzo zbliżony wynik dla wypłat średnich i niskich. 


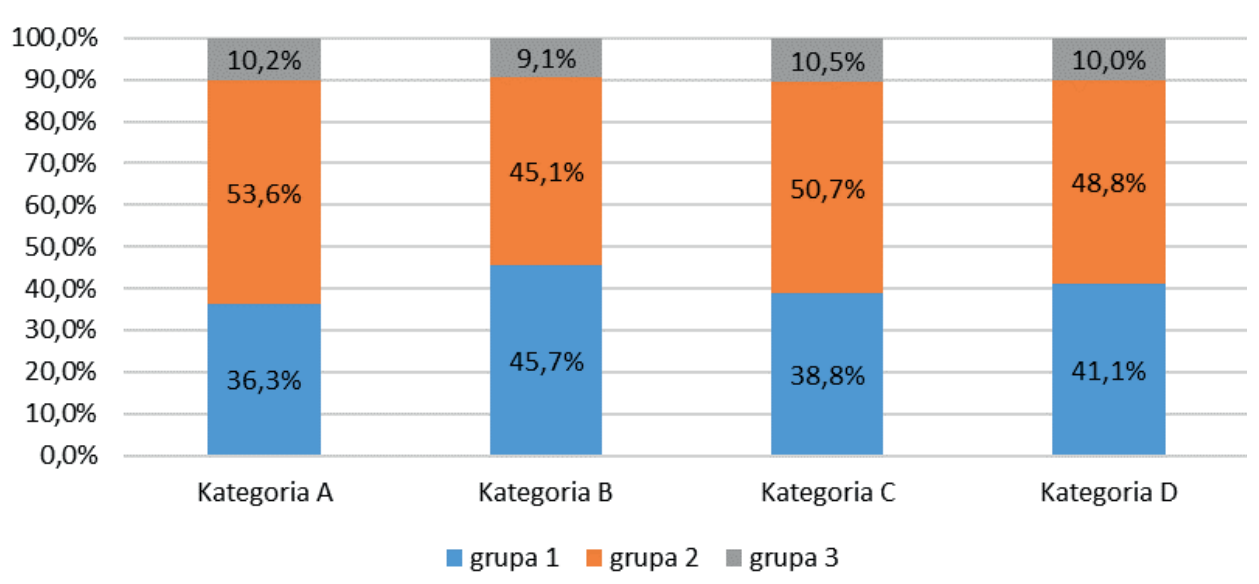

Rysunek 11. Struktura wielkości pojedynczych wypłat w wybranych kategoriach miejscowości Źródło: opracowanie własne na podstawie danych uzyskanych od operatora sieci

Podsumowując wyniki analizy liczby i wielkości wypłat dla wypłat z bankomatów w poszczególnych kategoriach miejscowości, można stwierdzić, iż wskazują one, iż największy zysk można uzyskać z bankomatów zainstalowanych w miejscowościach kategorii B. W tych bankomatach dokonuje się najwięcej wypłat dziennie, jednocześnie przy najmniejszej wielkości tej wypłaty. Dodatkowo w bankomatach z miejscowości kategorii B występują najczęściej wypłaty do $100 \mathrm{zł}$.

Pomimo wskazania bankomatów z miejscowości B jako przynoszących potencjalnie największy zysk należy zwrócić uwagę na fakt, iż w ujęciu ogólnym różnica w strukturze wypłat w bankomatach zlokalizowanych w miejscowościach o różnych kategoriach dostępności nie jest już tak znacząca jak dla typów lokalizacji.

\subsection{Wyniki analizy dla bankomatów w podgrupach typów lokalizacji i kategorii miejscowości}

We wcześniejszych analizach jako czynniki lokalizacyjne brano pod uwagę oddzielnie typ lokalizacji oraz kategorię miejscowości. Takie podejście dało możliwość wskazania, który z czynników bardziej różnicuje strukturę wypłat, i jednocześnie określenia typu lokalizacji, który daje największe zyski. Z perspektywy zarządcy interesujące może być jeszcze dokładniejsze sprecyzowanie lokalizacji, w których warto instalować bankomat, czyli określenie, w jakich bankomatach jest dużo wypłat o niskich wartościach.

$\mathrm{W}$ ostatniej części pracy przedstawiono wyniki związane z analizą wpływu lokalizacji, biorąc pod uwagę łącznie oba czynniki - typ lokalizacji oraz kategorię miejscowości. W związku z tym, iż w niektórych kategoriach lokalizacyjnych występuje mała liczba bankomatów, uzyskane wyniki trudno potraktować jako 
ogólną prawidłowość, a jedynie jako wynik badania pilotażowego, który może być podstawą hipotezy wymagającej dokładniejszej analizy dla większej liczby bankomatów. W tej analizie zamiast średnich wielkości wypłat zbadano średnie pojedyncze wypłaty, gdyż te wartości, wraz z liczbą wypłat, mają bezpośrednie przełożenie na zyski.

Tabela 6. Podstawowe statystyki dla średnich liczb wypłat z bankomatów o tym samym typie lokalizacji i kategorii dostępności

\begin{tabular}{|l|r|c|r|r|r|r|r|r|}
\hline \multirow{2}{*}{ Typ lokalizacji } & \multicolumn{2}{|c|}{ Kategoria A } & \multicolumn{2}{c|}{ Kategoria B } & \multicolumn{2}{c|}{ Kategoria C } & \multicolumn{2}{c|}{ Kategoria D } \\
\cline { 2 - 10 } & $\begin{array}{c}\text { Śred- } \\
\text { nia }\end{array}$ & $\begin{array}{c}\text { Wsp. } \\
\text { zmien. } \\
{[\%]}\end{array}$ & $\begin{array}{c}\text { Śred- } \\
\text { nia }\end{array}$ & $\begin{array}{c}\text { Wsp. } \\
\text { zmien. } \\
{[\%]}\end{array}$ & $\begin{array}{c}\text { Śred- } \\
\text { nia }\end{array}$ & $\begin{array}{c}\text { Wsp. } \\
\text { zmien. } \\
{[\%]}\end{array}$ & Średnia & $\begin{array}{c}\text { Wsp. } \\
\text { zmien. } \\
{[\%]}\end{array}$ \\
\hline Centrum handlowe & 146,66 & 15,65 & 199,11 & 38,83 & 155,39 & 54,428 & 148,76 & 53,46 \\
\hline Hipermarket & 159,91 & 20,24 & 186,54 & 34,92 & 134,68 & 26,39 & 120,394 & 42,15 \\
\hline Oddział bankowy & 55,67 & 23,91 & 77,13 & 57,24 & 65,39 & 50,04 & 77,04 & 67,76 \\
\hline Sklep & 137,063 & 26,56 & 148,40 & 34,05 & 141,54 & 38,76 & 151,90 & 8,99 \\
\hline Stacja paliw & 115,38 & 35,55 & 138,56 & 49,54 & - & - & 101,79 & 0,01 \\
\hline
\end{tabular}

Źródło: opracowanie własne na podstawie danych uzyskanych od operatora sieci

Tabela 7. Podstawowe statystyki dla średnich pojedynczych wypłat z bankomatów o tym samym typie lokalizacji i kategorii dostępności

\begin{tabular}{|c|c|c|c|c|c|c|c|c|}
\hline \multirow[b]{2}{*}{ Typ lokalizacji } & \multicolumn{2}{|c|}{ Kategoria A } & \multicolumn{2}{|c|}{ Kategoria B } & \multicolumn{2}{|c|}{ Kategoria C } & \multicolumn{2}{|c|}{ Kategoria D } \\
\hline & $\begin{array}{c}\text { Średnia } \\
\text { [PLN] }\end{array}$ & $\begin{array}{c}\text { Wsp. } \\
\text { zmien. } \\
{[\%]}\end{array}$ & $\begin{array}{c}\text { Śred- } \\
\text { nia } \\
{[\text { PLN] }}\end{array}$ & $\begin{array}{c}\text { Wsp. } \\
\text { zmien. } \\
{[\%]}\end{array}$ & $\begin{array}{c}\text { Śred- } \\
\text { nia } \\
{[\text { PLN] }}\end{array}$ & $\begin{array}{c}\text { Wsp. } \\
\text { zmien. } \\
{[\%]}\end{array}$ & $\begin{array}{c}\text { Śred- } \\
\text { nia } \\
{[\text { PLN] }}\end{array}$ & $\begin{array}{c}\text { Wsp. } \\
\text { zmien. } \\
{[\%]}\end{array}$ \\
\hline Centrum handlowe & 405,165 & 30,78 & 333,28 & 23,68 & 376,10 & 20,41 & 399,60 & 0,38 \\
\hline Hipermarket & 296,16 & 8,294 & 402,52 & 32,24 & 420,22 & 5,56 & 347,78 & 14,87 \\
\hline Oddział bankowy & 405,165 & 30,78 & 333,28 & 23,68 & 376,10 & 20,41 & 399,60 & 0,38 \\
\hline Sklep & 364,28 & 12,99 & 273,55 & 17,06 & 383,71 & 30,27 & 297,28 & 15,45 \\
\hline Stacja paliw & 559,57 & 20,13 & 480,72 & 20,10 & - & - & 457,50 & 24,75 \\
\hline
\end{tabular}

Źródło: opracowanie własne na podstawie danych uzyskanych od operatora sieci

Wyniki zamieszczone w Tabeli 6 potwierdzają wnioski, które zostały sformułowane w podpunktach 4.1 i 4.2. Czynnikiem, który ma znacznie większy wpływ na liczbę wypłat, jest typ lokalizacji. Bankomaty zlokalizowane w tej samej kategorii miejscowości różnią się znacząco w liczbie wypłat w zależności od typu lokalizacji. Przykładowo: z bankomatów zlokalizowanych w miejscowościach kategorii A wypłaca się gotówkę przeciętnie 55 razy, jeśli jest to oddział bankowy, 115 razy dla stacji benzynowej, a 159 razy w przypadku hipermarketu. Podobne dysproporcje występują dla miejscowości o innych kategoriach dostępności. Patrząc z perspektywy typu lokalizacji, zauważamy, że jedynie w przypadku bankomatów w hipermarketach kategoria miejscowości różnicuje znacząco przeciętną 
liczbę wypłat. Dla pozostałych typów lokalizacji wypłaty w bankomatach z miejscowości o różnych kategoriach dostępności są zbliżone.

Analizując struktury wypłat dla poszczególnych podgrup lokalizacyjnych, zauważono, iż uszczegółowienie lokalizacji w żaden sposób nie wpłynęło na zmniejszenie zróżnicowania w średniej liczbie wypłat z poszczególnych bankomatów. Współczynniki zmienności mają zazwyczaj zbliżoną wartość do tych, które uzyskano dla większych grup. Oznacza to, iż - mimo zawężenia typu lokalizacji i uwzględnienia dwóch charakterystyk - nie uzyskano w poszczególnych podgrupach bardziej zbliżonych wyników liczby wypłat niż w przypadku grupowania na podstawie jednej charakterystyki.

Wyniki zamieszczone w Tabeli 7, dotyczące średniej pojedynczej wypłaty, potwierdzają wnioski uzyskane dla analizy średniej liczby wypłat. Typ lokalizacji znacznie bardziej różnicuje średnią pojedynczą wypłatę z bankomatu niż kategoria dostępności bankomatu. Przykładowo: dla bankomatów zainstalowanych w miejscowości z kategorii A, dla bankomatów z hipermarketów średnia wynosi około 300 zł, a dla stacji benzynowej prawie 560 zł. Takich różnic nie ma pomiędzy bankomatami z tego samego typu lokalizacji A w innych kategoriach miejscowości. Również dla średniej pojedynczej wypłaty, pomimo zawężenia grupy bankomatów, nie uzyskano mniejszych wartości współczynnika zmienności, co gwarantowałoby mniejszą rozpiętość wartości średnich dla bankomatów z tej samej lokalizacji oraz z tej samej kategorii miejscowości.

\section{Wnioski}

W ostatnim okresie liczba wypłat z bankomatów w Polsce zmalała. Przykładowo: w I kwartale 2019 roku wypłaty gotówki w bankomatach opiewały na łączną kwotę 78,9 mld zł, czyli o 6 mld zł mniej niż w kwartale poprzednim. Spadek liczby wypłat $\mathrm{z}$ bankomatów może doprowadzić do obniżenia zysków operatorów sieci bankomatowych. W konsekwencji zarządcy sieci mogą się decydować na likwidowanie bankomatów w lokalizacjach, które charakteryzują się niską liczbą wypłat. Jednocześnie mogą oni instalować nowe bankomaty tylko w lokalizacjach, w których mogą liczyć na dużą liczbę wypłat. Takie działanie może prowadzić do ograniczenia dostępności bankomatów w niektórych typach lokalizacji.

W tym kontekście przeprowadzona analiza wykazała, że bankomaty w niektórych typach lokalizacji charakteryzują się wyższą liczbą wypłat i jednocześnie niewysoką ich wielkością. Taką lokalizacją są centra handlowe, które - jak wynika z tej analizy - powinny stać się miejscami instalowania nowych bankomatów. Na podstawie przeprowadzonej analizy bankomaty powinny znikać z oddziałów bankowych, gdyż ta lokalizacja charakteryzuje się małą liczbą wypłat, ale o stosunkowo dużej wartości. Również bankomaty znajdujące się na stacjach paliw nie 
zawsze są rentowne. Wynika to z faktu, iż jest w nich dość duża wielkość wypłaty (co podnosi koszty), a jednocześnie przeciętna liczba wypłat.

$\mathrm{Z}$ drugiej jednak strony nawet w grupie bankomatów o tym samym typie lokalizacji i kategorii miejscowości są bankomaty znacznie różniące się od siebie pod względem liczby wypłat. Ten fakt prowadzi do wniosku, że w przypadku zainstalowania nowego bankomatu w lokalizacji, w której średnia liczba wypłat jest wysoka, a wielkość wypłat niska, nie ma gwarancji podobnej struktury wypłat. Choć z pewnością szansa na to jest znacznie większa niż dla innych lokalizacji.

Autorzy mają świadomość, iż istotnym ograniczeniem przeprowadzonych badań jest fakt wykorzystania danych dotyczących wypłat z bankomatów sprzed ponad 7 lat. W okresie od 2012 do 2019 zmieniły się uwarunkowania dotyczące wypłat z bankomatów oraz płatności mobilnych. Można domniemywać, iż te zmiany wpłynęły na nawyki użytkowników bankomatów związane z formami płatności, jakie preferowali. Z drugiej jednak strony - jak wynika z danych publikowanych na stronach Narodowego Banku Polskiego ${ }^{3}$ - ogólna liczba wypłat z bankomatów w latach 2018-2019 jest zbliżona do liczby wypłat z okresu 2011-2012. Dodatkowo z informacji, jakie uzyskano od operatora, wynika, iż mimo upływu lat mentalność związana ze strukturą wypłat z bankomatów nie zmieniła się aż tak diametralnie, aby przeprowadzone badania były nieaktualne.

\section{Bibliografia}

Amromin E., Chakravorti S. (2007), Debit card and cash usage: a cross-country analysis, Technical report, Federal Reserve Bank of Chicago, Chicago.

Boeschoten W.C. (1998), Cash management, payment patterns and the demand for money, „De Economist”, t. 146, nr 1, s. 117-142.

Brentnall A.R., Crowder M.J., Hand D.J. (2008), A statistical model for the temporal pattern of individual automated teller machine withdrawals, „Applied Statistics”, t. 57, nr 1, s. 43-59.

Brentnall A.R., Crowder M.J., Hand D.J. (2010), Predicting the amount individuals withdraw at cash machines using a random effects multinomial model, „Statistical Modelling”, t. 10, nr 2, s. 197-214.

Carlsen M., Storgaard P.E. (2010), Dankort payments as a timely indicator of retail sales in Denmark, Danmarks Nationalbank Working Papers, nr 66.

Cleveland W.S., Devlin S.J. (1980), Calendar Effects in Monthly Time Series: Detection by Spectrum Analysis and Graphical Methods, „Journal of the American Statistical Association”, t. 371 , nr 75, s. 487-496.

Esteves P.S. (2009), Are ATM/POS Data Relevant When Now casting Private Consumption?, Banco de Portugal Working Paper, nr 25.

Górka J. (2011), Rozwój sieci bankomatów w Polsce a opłaty interchange i surcharge, „Gospodarka Narodowa", nr 7-8, s. 89-112.

Górka J. (2013), Efektywność instrumentów platniczych w Polsce, Wydawnictwo Naukowe Wydziału Zarządzania Uniwersytetu Warszawskiego, Warszawa.

3 Raport NPB dla II kwartału 2019 roku. 
Górka J., Chodnicka P. (2012), Prognoza rozwoju sieci bankomatów w Polsce, [w:] J. Sokołowski, M. Sosnowski, A. Żabiński (red.), Polityka ekonomiczna, „Prace Naukowe Uniwersytetu Ekonomicznego we Wrocławiu", nr 246, s. 96-105.

Gurgul G., Suder M. (2012), Efekt kalendarza wypłat z bankomatów sieci Euronet, „Zeszyty Naukowe Wyższej Szkoły Ekonomii i Informatyki w Krakowie”, nr 8, s. 25-42.

Gurgul H., Suder M. (2013a), Modeling of Withdrawals from Selected ATMs of the „Euronet” Network, „Managerial Economics”, t. 13, s. 65-82.

Gurgul H., Suder M. (2013b), The properties of ATMs development stages - an empirical analysis, „Statistics in Transition”, t. 3, s. 443-466.

Gurgul H., Suder M. (2013c), Rozkład prawdopodobieństwa dziennych wypłat z bankomatów, „Wiadomości Statystyczne", t. 58, nr 4, s. 1-22.

Gurgul H., Suder M. (2015), Prognozowanie wypłat z bankomatów, „Wiadomości Statystyczne”, t. 60 , nr 8 , s. $25-48$.

Gurgul H., Suder M. (2018), Impact of ATM location on its profitability in Malopolskie and Podkarpackie provinces, „Managerial Economics”, t. 19, s. 49-73.

Holden K., El-Bannany M. (2004), Investment in information technology systems and other determinants of bank profitability in the UK, „Applied Financial Economics”, t. 14, s. 361-365.

Kondo K. (2010), Do ATMs influence bank profitability in Japan?, „Applied Economics Letters”, t. $17, \mathrm{nr} 3$, s. $297-303$.

Kruskal W.H., Wallis A. (1952), Use of ranks in one-criterion variance analysis, „Journal of the American Statistical Association”, t. 47, nr 260,, s. 583-621.

Kufel T. (2010), Ekonometryczna analiza cykliczności procesów gospodarczych o wysokiej częstotliwości obserwowania, Wydawnictwo Naukowe Uniwersytetu Mikołaja Kopernika, Torun.

Mester L. (2009), Changes in the use of electronic means of payment: 1995-2007, „Business Review", nr Q3, s. 29-37.

Polasik M., Maciejewski K. (2017), Skutki obniżenia opłaty interchange na polskim rynku kart płatniczych, „Annales Universitatis Mariae Curie-Skłodowska”, t. 6, nr 51, s. 331-341.

Snellman H., Viren M. (2009), ATM networks and cash usage, „Applied Financial Economics”, t. 19 , nr 10, s. $841-851$.

\title{
The Structure of Withdrawals from ATMs Depending on Their Location Type
}

\begin{abstract}
One of the main goals of ATMs' management is a thorough analysis of the structure of withdrawals for individual ATM and groups of ATMs installed in similar places. This type of research constitutes a necessary background for decision making about the installation or de-installation of ATMs in each location type. The most important factors from the point of view of the profitability of the ATM is the number of withdrawals and the value of a single withdrawal. A number of withdrawals from ATM determine the revenue of ATM owners due to interchange fees and advertisements displayed in ATMs at the time of withdrawal. A large number of withdrawals generate large revenues. The value of a single withdrawal has an impact on costs. The larger withdrawals generate larger costs including preparation and delivery of cash for an ATM and "freezing" of funds in the ATM. The main goal of this research was to identify locations of the ATMs generating largest revenues i.e. locations with a large number of withdrawals and small value of single withdrawal. In addition, we tested hypotheses concerning differences in a number of withdrawals and values of single withdrawals from ATMs installed in different types of locations.
\end{abstract}


In this paper, we used a time series of numbers and values of withdrawals from ATMs supplied by one of the largest ATMs networks in Poland. The data set concerns ATM's located in Małopolskie and Podkarpackie provinces in Poland. In the research concerning the structure of withdrawals, we have used basic descriptive statistics and selected statistical tests.

The study concluded with the selection of locations where with high probability installation of ATM would generate profits. The results of the analysis may be of interest to owners of networks with respect of the choice of location type.

Keywords: location of ATMs, structure of withdrawals, replenishment management

JEL: G21, G32, G39

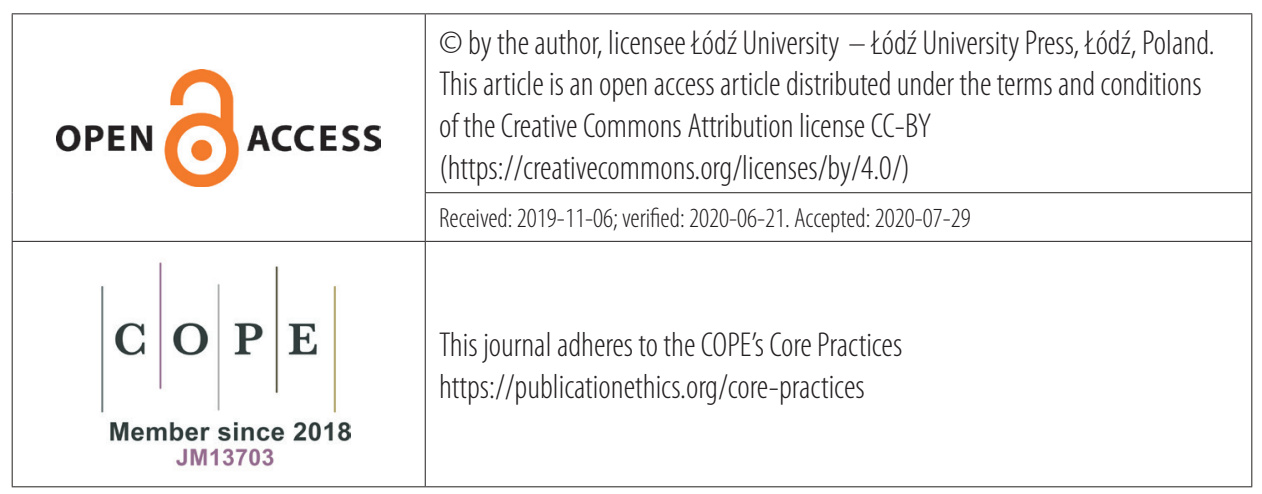


